\title{
Imagen y texto en las revistas de humor satírico. Una aproximación al underground en España durante el tardofranquismo ${ }^{1}$
}

\author{
Francisca Lladó Pol \\ Universitat de les Illes Balears \\ Fracisca.Ilado@uib.es
}

RESUMEN: Durante el tardofranquismo las revistas de humor satírico contribuyeron a la génesis del cómic adulto a través de unos textos e imágenes que se acercaban a los movimientos contraculturales. Si bien su finalidad era la de criticar a la sociedad española en sus diversas vertientes, además podemos detectar una lenta entrada del underground a través de la reutilización de imágenes del cómic americano y de los tebeos españoles anteriores. Se trataba de efectuar una trasgresión en la barrera que separa al significante del significado de los componentes formales que favoreciera la introducción de mensajes ideológicos críticos. De este modo las imágenes referenciales originales transmudadas adquieren otros significados y se convierten en el vehículo para la sátira. Esta renovación del lenguaje específico del cómic a través de nuevas formas de representación y contenidos dejará un campo abonado para configurar el cómic adulto de la transición.

PALABRAS CLAVE: Tardofranquismo; Revistas de humor satírico; Underground; Cómic americano; Tebeos de postguerra; Cultura visual.

\section{Image and Text in Satirical Humor Magazines. An Approach to the Underground in Spain during the Late Franco Regime}

ABSTRACT: During the late Franco regime satirical humour magazines contributed to the genesis of adult comics through texts and images that approached countercultural movements. Although its purpose was to criticize Spanish society in its various aspects, we can also detect a slow entry of the underground through the reuse of images from the American comic and previous Spanish comics. The aim was to make a transgression in the barrier that separates the signifier from the meaning of the formal components that favored the introduction of critical ideological messages. In this way the original transmuted referential images acquire other meanings and become the vehicle for satire. This renewal of the specific language of the comic through new forms of representation and content will leave a fertile field to configure the adult comic of the transition.

KEYWORDS: Late Franco's Regime; Satirical Humour Magazines; Underground; American Comic; Post-War Comics; Visual Culture.

Recibido: 15 de diciembre 2017 / Aceptado: 25 de mayo de 2018.

\section{Las revistas de humor satírico como espacio de libertad}

Como apuntó Umberto Eco en Apocalípticos e Integrados (1988: 269), «no es cierto que los cómics sean una diversión inocua». A partir de dicha afirmación, el objeto de este artículo es el análisis de las revistas de humor satírico² publicadas en España entre finales de los años sesenta del pasado siglo hasta 1975 con la finalidad de establecer una línea de conexión con los contenidos de revistas extranjeras de raigambre underground, los tebeos españoles y el cómic americano. Para abordar el tema nos hemos centrado en el empleo crítico que los nuevos dibujantes españoles hicieron de las manifestaciones

Cómo citar este artículo: LLADÓ POL, Francisca, «Imagen y texto en las revistas de humor satírico. Una aproximación al underground en España durante el tardofranquismo", Boletín de Arte-UMA, n. ${ }^{\circ}$ 39, Departamento de Historia del Arte, Universidad de Málaga, 2018, pp. 139-154, ISSN: 0211-8483, DOI: http://dx.doi.org/10.24310/ BoLArte.2018.v0i39.4865 
mencionadas modificando sus características formales o de contenido. De este modo, conseguían introducir elementos de denuncia en un momento en el que la política de los últimos años del franquismo parecía propiciar un incipiente aperturismo. Estas circunstancias fueron aprovechadas por un grupo de editores y dibujantes que entendieron que era posible utilizar la imagen y el texto para reflejar una realidad más cercana y veraz que se oponía a la visión oficial.

La exposición adoptada presentará algunas temáticas, personajes o autores de referencia para establecer los paralelos con algunos ejemplos concretos de las producciones españolas de este periodo. Así se podrán vislumbrar las maniobras y tergiversaciones a las que se somete el punto de partida para emplearlo, a veces de forma soterrada, como vehículo de una crítica a la realidad política y social de estos años. Podremos constatar cómo la fractura de la barrera que separa -en cada caso- los significantes de sus significados manifiesta la transgresión de los modelos tanto en sus aspectos formales como en los contenidos. Frecuentemente este hecho hace que los resultados sean indefinibles si los intentamos ceñir a parámetros definitorios estrictos, porque siempre se caracterizan por ser ambiguos, híbridos y abigarrados. Por todo esto los términos se emplean -sin menoscabo de su precisión- con el significado más común y descriptivo, sin aspirar a establecer unas categorías filosóficas o estéticas más profundas que no son objetivo de nuestro trabajo.

Sin adentrarnos en el nacimiento y evolución de las revistas españolas de los años setenta, podemos decir que significaron el punto de partida del cómic adulto ${ }^{3}$ que se consolidó en la Transición (Lladó, 2001: 18). Marcaron las distancias con las publicaciones destinadas a un público infantil y juvenil alternando artículos de opinión con tiras cómicas, viñetas e ilustraciones que influyeron decididamente en dibujantes más jóvenes. Gracias a nuevas fórmulas narrativas se acercaron al medio circundante y realizaron metáforas de libertad para evitar una censura (Barrera: 1995) que no siempre pudieron evitar ${ }^{4}$.

\section{Las conexiones con el underground}

La llegada del underground a España se halla vinculada al cómic estadounidense, de modo que los autores nacionales inspirándose en obras de Robert Crumb, Gilbert Shelton o Spain Rodríguez y otros elementos contraculturales ${ }^{5}$ como la literatura o el teatro, introdujeron en sus viñetas una alternativa a la cultura oficial. Algunas de estas producciones fueron conocidas gracias a los viajes al extranjero, aunque no debemos olvidar la publicación en Italia en 1972 de La Cultura Underground de Mario Maffi. Obra que llegó a España en 1975 y que analiza el movimiento nacido en Estados Unidos caracterizado por la existencia de artistas que abandonaron el círculo intelectual de élite para dedicarse a la acusación, atacando los tabúes burgueses a través de la pornografía o la homosexualidad y ofreciendo una concepción lúdica de la vida que se concreta en el interés por la cultura oriental, la meditación o las comunas hippies. Gracias a dicho texto, sabrán de la existencia de un cómic clandestino y marginal en cuyas páginas trataban la manipulación de los medios de comunicación, la violencia, las drogas o la injusticia social (Dopico, 2005:24).

Unas percepciones que se reflejan en las páginas de La Codorniz (1941/1978), Hermano Lobo (1972/1976), El Papus (1973/1987) y Por Favor (1974/1978) (Tubau, 1987: 241), no tanto por la imitación del estilo Crumb, sino por sus temáticas al margen de la oficialidad. Los dibujantes no dudaron, tal como ocurrió en Estados Unidos, en criticar el género de superhéroes, la Guerra del Vietnam, la crisis del petróleo, demandaron derechos civiles y cuestionaron instituciones como la religión y la familia a la vez que radiografiaron el desarrollismo franquista, la corrupción y las relaciones con EE. UU. En su afán de denuncia, lo hicieron en bloque, desmitificando las bondades del capitalismo americano y las mejoras del aperturismo del tardofranquismo. Si bien formalmente sus dibujos se encuentran alejadas del modelo incisivo del undergound, las producciones españolas están enmarcadas por un esquematismo ajeno a las producciones europeas y americanas de carácter comercial. De modo que se puede afirmar que sus principios conceptuales eran coincidentes, ya que ambos se muestran contrarios a la política hegemónica basada en el paternalismo político. Pero también sabían que el cambio no se podía conseguir desde una realidad ajena, ya que la española requería primero conseguir la democracia para luego adentrarse en una sociedad más plural. En paralelo aparecieron las primeras publicaciones marginales que Dopico ha definido como «expresiones preunderground» (2005: 31) y que tuvieron lugar en Barcelona. 
Un estado de efervescencia que estimuló la producción de los semanarios de humor generando una verdadera sinergia, ya que se retroalimentaron del componente ideológico que había llegado a enaltecer la marginación como modelo de conducta. Destaca el colectivo El Rrollo enmascarado, en cuya primera editorial puntualizaron las diferencias entre el movimiento americano y el nuevo cómic español a partir de la necesidad de buscar temas netamente españoles tomados de la calle y basados en la crítica social:

Pues no cabe duda de que la deuda a los dibujantes underground yanquis es importante en el desarrollo del modo de hacer historietas del grupo. $Y$ esto hace que sus dibujos se distancien de los que habitualmente se ven en el mercado: nada de Mortadelo y Filemón, ni asomos de Roberto Alcázar y Pedrín (...). Esto los hace apartarse aún más de la cultura oficial ya que al tomar los temas netamente españoles, tomados de la calle que frecuentan, la crítica social se convierte en más intensa (El Rrollo enmascarado, 1975: 3).

Aunque desde ámbitos diferentes, eran conscientes que el underground era un punto de partida para la renovación del cómic, ya bien desde el medio comercial o alternativo.

\section{Las revisiones de los tebeos españoles}

Una de las primeras emulaciones corresponde al Guerrero del Antifaz, personaje creado por Manuel Gago García por Editorial Valenciana entre 1944 y 1966. Según Salvador Vázquez de Parga constituye la síntesis de la ideología franquista a través de la identificación entre la Edad Media y la España franquista gracias al trípode ideológico de raza, religión y patria (1980: 78), una opinión que ha sido matizada por estudios posteriores que ven en el españolismo del protagonista otros puntos en común con algunos sectores de izquierda, así como con los contenidos que se explicaban en los manuales de historia de la época de la Restauración (Marimón, 2005: 27). En todo caso, ofrece una visión maniquea que opone el régimen a la política de izquierdas. Una actitud que encontramos igualmente en El Intruso del Equipo Crónica de 1969, una critica al franquismo a través de la fusión de una obra icónica de la modernidad como es el Guernica con el Guerrero del Antifaz, en clara alusión a la represión de finales de los años sesenta. Dicho lo cual y al analizar las revisiones de El Guerrero del Antifaz no debemos dudar en considerar la doble referencia al estudiar el personaje.

Por Favor y El Papus transgreden la alusión al franquismo para identificar al protagonista con Henry Kissinger, extrapolando sus principios al secretario de estado de Estados Unidos y su política internacional belicista. En El Papus, Fer (José Antonio Fernández) [1], reproduce simétricamente las seis primeras viñetas, las cuales han sido recortadas de un original siguiendo los parámetros de los cuadernos de aventuras. Temáticamente se centra en la crisis de petróleo de 1973 y la actitud de Estados Unidos frente a los países árabes. El Guerrero del Antifaz lucha contra sus enemigos naturales, con alusiones al premio Nobel de la paz por su mediación en la guerra del Vietnam y su intervención en Chile a la hora de derrocar el gobierno democrático de Salvador Allende y potenciar la dictadura de Augusto Pinochet. El formato de las tres viñetas siguientes, ya dibujadas por Fer, nos anuncian que está soñando con el petróleo, para finalmente ser despertado por su mujer. Circunstancia que nos lleva a establecer un símil con uno de los clásicos de cómic americano como Little Nemo in Slumberland de Winsor McCay (1905-1911), cuyo personaje siempre se despierta angustiado en la última viñeta (Masota, 1982: 32).

Romeu (Jaume Romeu Muller) publicó en Por Favor «Guerrero del antifaz revisited» ${ }^{6}$, introduciendo una viñeta extraída de un ejemplar de Gago, para organizar la página en una estructura asimétrica con un dibujo catalogado como feísta según el modelo de Charlie Hebdo (Fontes y Menéndez, 2004: 537). Cada viñeta configura una historia en sí misma, primeramente la secretaria le pasa una llamada de Golda Meir para ver cuando recogerá la medalla por haber negociado el fin de la guerra del Yom Kipur; en la segunda, aparece amordazado para evitar que grite improperios contra los musulmanes y no pueda oírlo Muamar el Gadafi, pasando posteriormente a referencias a Boabdil y Fernando el Católico. En ambos casos los atributos de superioridad se trasponen a Kissinger, ya que lucha por conseguir sus objetivos.

Otro de los cuadernos de aventuras es Hazañas Bélicas, publicado a partir de 1948 por Ediciones Toray. Las ilustraciones caracterizadas por su gran detallismo fueron realizadas en principio por Boixcar (Guillermo Sánchez Boix) y se 


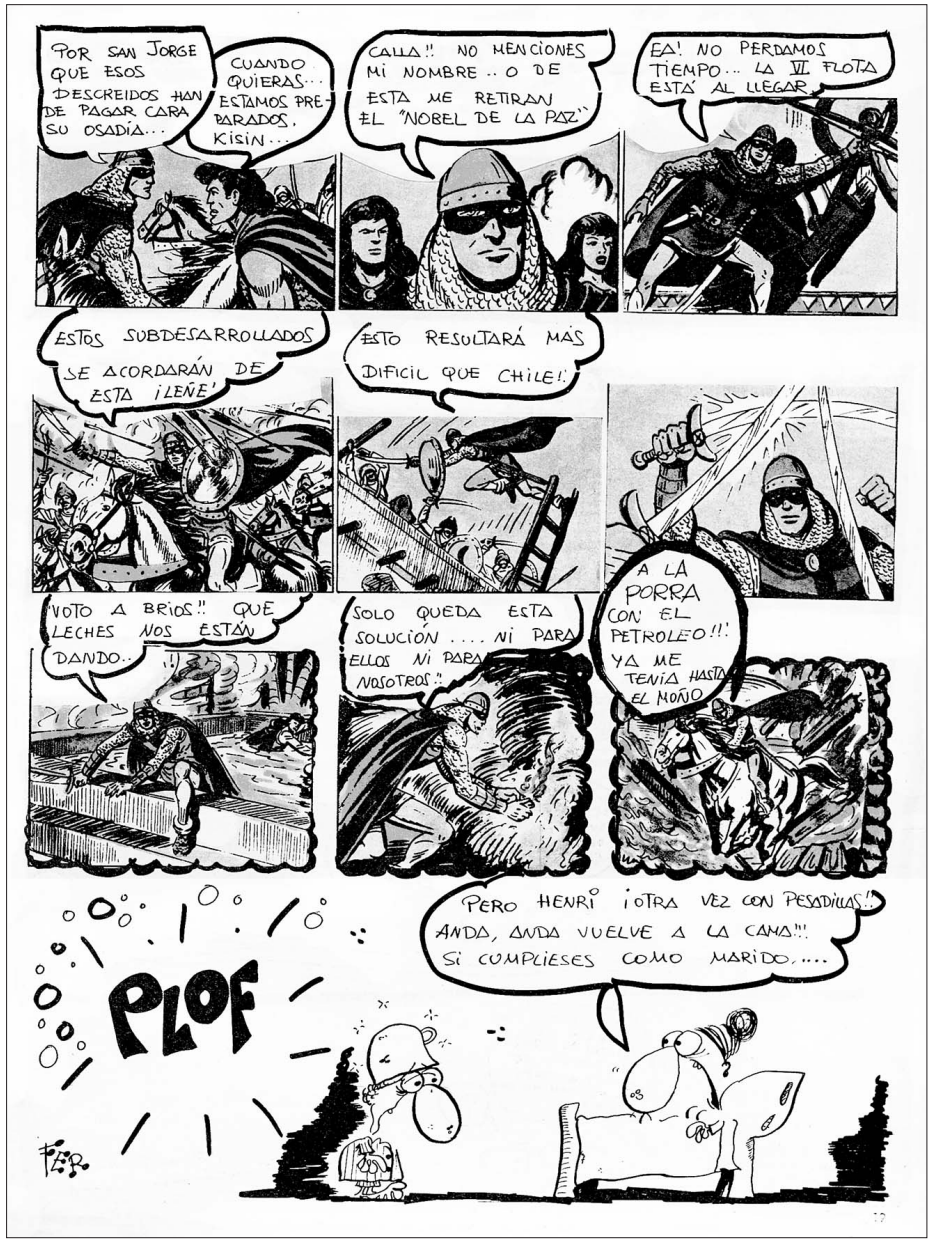

1. Fer, «El guerrero del antifaz», El Papus, n. ${ }^{\circ} 70,15 / 02 / 1975$, p. 19. Col. Biblioteca Nacional de Catalunya centran en la temática de guerra, inicialmente en la Segunda Guerra Mundial y a partir de 1950 el escenario se desplazará a la Guerra de Corea y de Vietnam. De modo que aunque volvemos a encontrarnos ante episodios maniqueos donde los militares japoneses son cobardes y crueles, mientras que los rusos son el compendio de todos los vicios, Terenci Moix partiendo de que el conflicto está en el fuero interno de cada personaje, matiza esta idea apuntando que:

Sociológicamente, la importancia de Hazañas Bélicas radica en un progresismo falsificado, que quiere llegar a la condena de la guerra después de haber acostumbrado al lector a no poder pasarse sin ella. Es extraño que Hazañas Bélicas pretenda condenar unos hechos sin los cuales no existiría la colección. Las contradicciones aumentan cuando nos damos cuenta de que esta continua apología de la paz se ha puesto casi siempre del favor del más fuerte, condenando a los ojos infantiles a todos aquellos enemigos que no encajaban en la idea de «causa justa» fomentada oficialmente (2007: 226).

De carácter auto-conclusivo no se repiten los personajes, ya que la intriga consistirá en desarrollar las diversas reacciones ante una situación extrema (Altarriba, 2001:267). Guillén (Juan José Guillén Zambrano) publicó en Por Favor dos páginas bajo el título de «El cabo Ismael» [2] reproduciendo la portada de uno de los cuadernos de aventuras cuyo escenario es la Guerra de Vietnam. Siguiendo a Boixcar, dibuja de forma realista los uniformes de los soldados americanos así como los tanques utilizados en la contienda. Al tratarse de una portada, no hay diálogos, sino que el protagonismo radica en la imagen y la frase al pie actúa como anclaje "Contribución a la campaña de rearme ideológico». 
2. Guillén, «El cabo Ismael», Por Favor, n. ${ }^{0} 24,16 / 12 /$

1974. Col. Arxiu històric de la ciutat de Barcelona

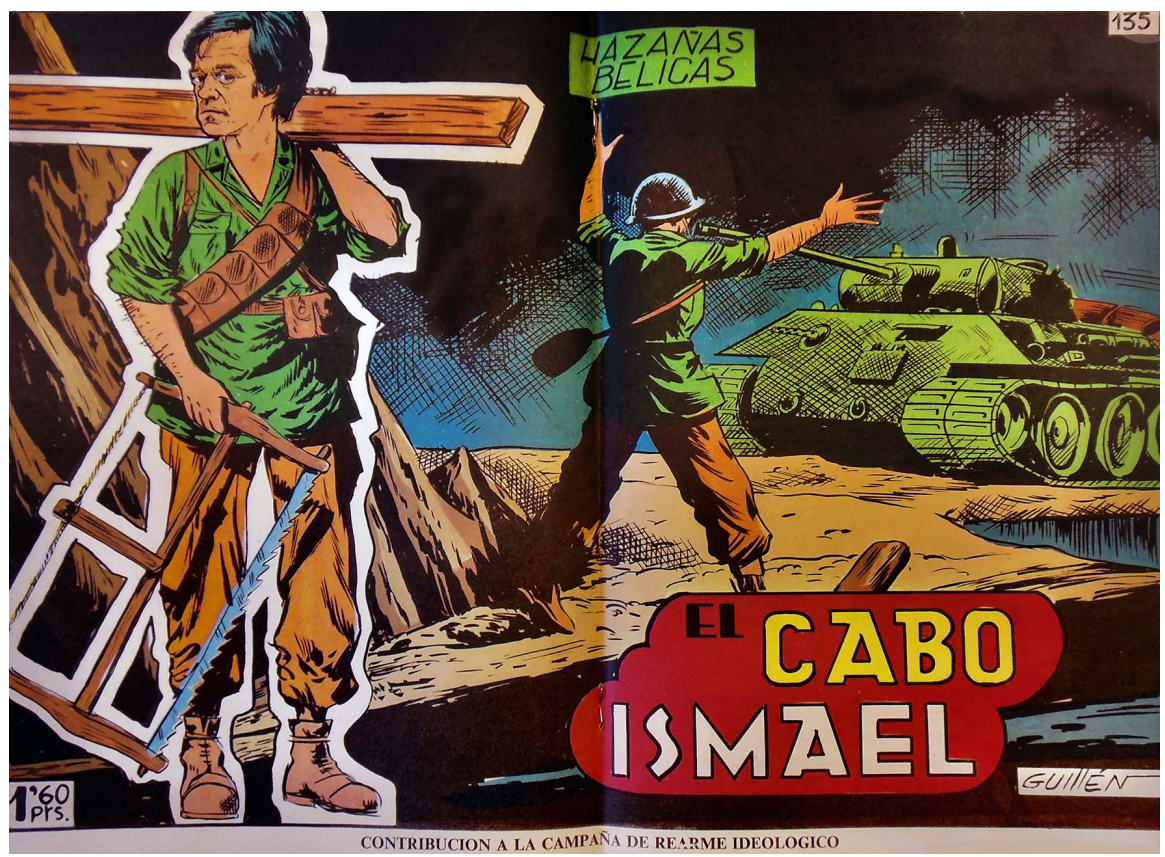

En un momento en que la CIA apunta que el conflicto no puede ganarse sólo a través de los medios militares, sino evitando la infiltración comunista, la frase adquiere sentido a través de dos personajes opuestos: un militar norteamericano de espaldas, mientras que «el cabo Ismael», mira al espectador sin llevar otras armas que sus herramientas de carpintero. Aquello que verdaderamente interesa es el compromiso personal y la coherencia ética del protagonista. Tanto en la relectura de El Guerrero del Antifaz como en Hazañas Bélicas, se observa el rechazo a la política norteamericana, un tema que recuperaremos al analizar las referencias a los cómics americanos.

Otras historietas fueron utilizadas para criticar la política estatal en su fase aperturista así como para presentar el nuevo modelo de sociedad. Roberto Alcázar y Pedrín es un tebeo de protagonismo compartido dibujado por Eduardo Vañó y publicado por editorial Valenciana entre 1940 y 1975, de modo que coexiste con las revistas de humor satírico. El protagonista evoluciona en su profesión, de periodista a agente de la Interpol, pasando por detective. Si bien defiende los intereses del capitalismo, no se detecta una identificación con la ideología más reaccionaria (Altarriba, 2001: 240-251) pese al parecido físico de Roberto Alcázar con José Antonio Primo de Rivera. Guillén recupera este tebeo en dos ocasiones para la revista Por Favor. En la primera el título aparece tergiversado como "Julio Rodríguez Alcázar y Pedrín» [3] haciendo alusión al exministro de educación Julio Rodríguez Martínez, quien en su corta trayectoria expulsó al profesor de la Universidad Complutense de Madrid, Carlos París, director del departamento de Filosofía por su vinculación al Partido Comunista (Falcón, 2014). Guillén utiliza el trazo desdibujado de Vañó y presenta en primer plano a Roberto Alcázar asestándole un puñetazo a un joven de pelo largo y barba, arquetipo de los jóvenes de izquierdas. Recurre a la metáfora de la Torre Eiffel para referirse al filósofo París, mientras Pedrín, fiel a sus preceptos de «atizar mamporros» a quien salga de las normas establecidas (Vidal y otros, 1999: 23), está a punto de pegarle con un taburete gritándole «iVerás como te pelo, tío ‘masón’!». Una crítica a la censura política, que se repite en la portada del número 23 en la cual se lee «Asociaciones. El tiempo acercaba al monstruo "7 donde Roberto Alcázar y Pedrín vestidos con camisa azul intentan detener el reloj. Las alusiones están referidas al Espíritu del 12 de febrero, que en su punto tercero prometía la redacción de un Estatuto de derecho de asociación, siempre que se identificaran con los principios fundamentales del Movimiento que verá la luz el 21 de diciembre de 1974 (Garrido, 2010: 167). 


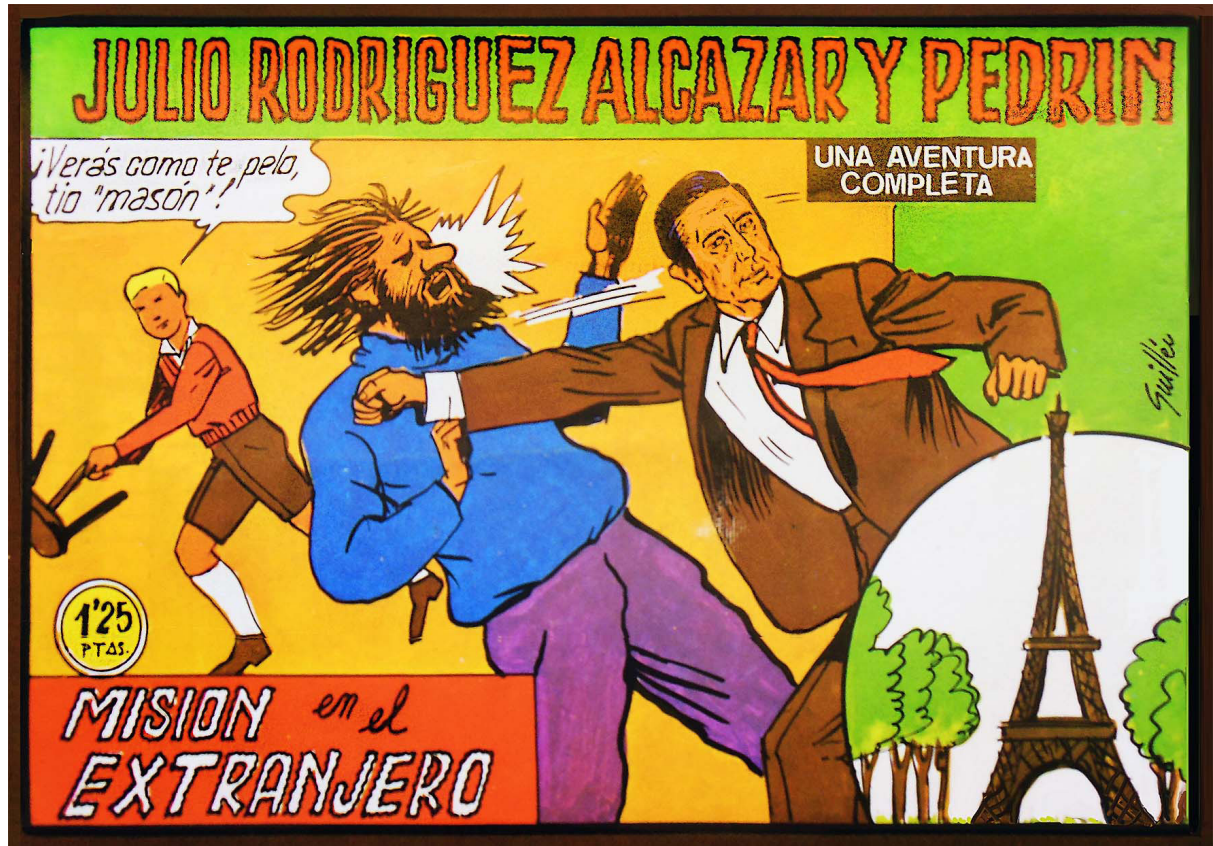

3. Guillén, «Julio Rodríguez Alcázar y Pedrín», Por Favor, n. ${ }^{\circ}$ 15, 10/06/1974, contraportada Col. Arxiu històric de la ciutat de Barcelona
El Espíritu del 12 de febrero fue uno de los temas más tratados en el año 1974, destacando dos páginas de Romeu en Por Favor bajo el título de «Calle Espíritu de Febrero, n. ${ }^{\circ}$ 12» [4], en alusión a 13 Rue del Percebe de Ibañez (Francisco Ibáñez Talavera) publicada en Tío Vivo de editorial Bruguera en 1961. Un inmueble abierto para que el lector pueda ver todos los personajes que lo habitan, aun cuando los mismos se ignoran entre sí. Ibañez presenta, según Juan Antonio Ramírez (1975: 158), la vida misma, unos personajes estereotipados de la España de los años sesenta, que serán transformados en los setenta a través de un dibujo rápido y esquemático. Los contenidos de Romeu, más que vinculados al aperturismo de Arias Navarro, se refieren a distintas cuestiones de la política internacional y sus consecuencias en España. En tres de los apartamentos se hace referencia a la CIA y la compra de periodistas a raíz del caso Watergate. Unos jóvenes de izquierdas ven como solución un pacto con la CIA, un grupo de militares plantean un acuerdo con el Partido Comunista ante la falta de financiación de la agencia americana, mientras que un periodista se lamenta de no haber recibido ninguna propuesta. No podemos pasar por alto algunas cuestiones sociales como el gurú que vive en la buhardilla o una joven arquitecta. En ambos casos se da un acercamiento a los nuevos perfiles de la sociedad, como la liberación de la mujer o el interés por la meditación, tan en boga entre los movimientos contraculturales.

Hay otros personajes de postguerra que fueron recuperados porque la represión, la tristeza, las desigualdades, el hambre y el afán de supervivencia aun pervivían. Unas pautas que a principios de los setenta eran diferentes pero coincidentes en su necesidad de cambio. Un ejemplo es Tribulete de Guillem Cifré publicado en Pulgarcito de editorial Bruguera, entre 1947 hasta 1986, aunque ya con otros dibujantes. El repórter Tribulete es un arquetipo de la vida barcelonesa de postguerra que sufre las humillaciones de su jefe así como penurias económicas. Para Antonio Altarriba (2001: 93), la gran tragedia del personaje radica en que nunca pasa nada, situación que le lleva a la rutina y a la frustración. Los espacios en que se mueve son imprecisos, es una historia de oficinas cuya trama argumental es la supervivencia de los periodistas ante la falta de noticias. Cuando el personaje es recuperado por Vives (Jordi Vives Cortès) ${ }^{8}$, la censura era otra, pero igualmente férrea, de allí que el médico le recomiende que cambie de trabajo. Podemos afirmar que se trata de cómic autonímico, ya que el dibujante apoyado por la historia del mismo e impulsado por la crítica pasa al terreno de la reflexión. El medio se convierte en fin y satiriza sobre la situación de desamparo y la lucha por la supervivencia. 
4. Romeu, «Calle Espíritu de Febrero, n. ${ }^{0} 12 "$, Por Favor, n. ${ }^{0} 22,2 / 12 / 1974$, p. 12. Col. Arxiu històric de la ciutat de Barcelona

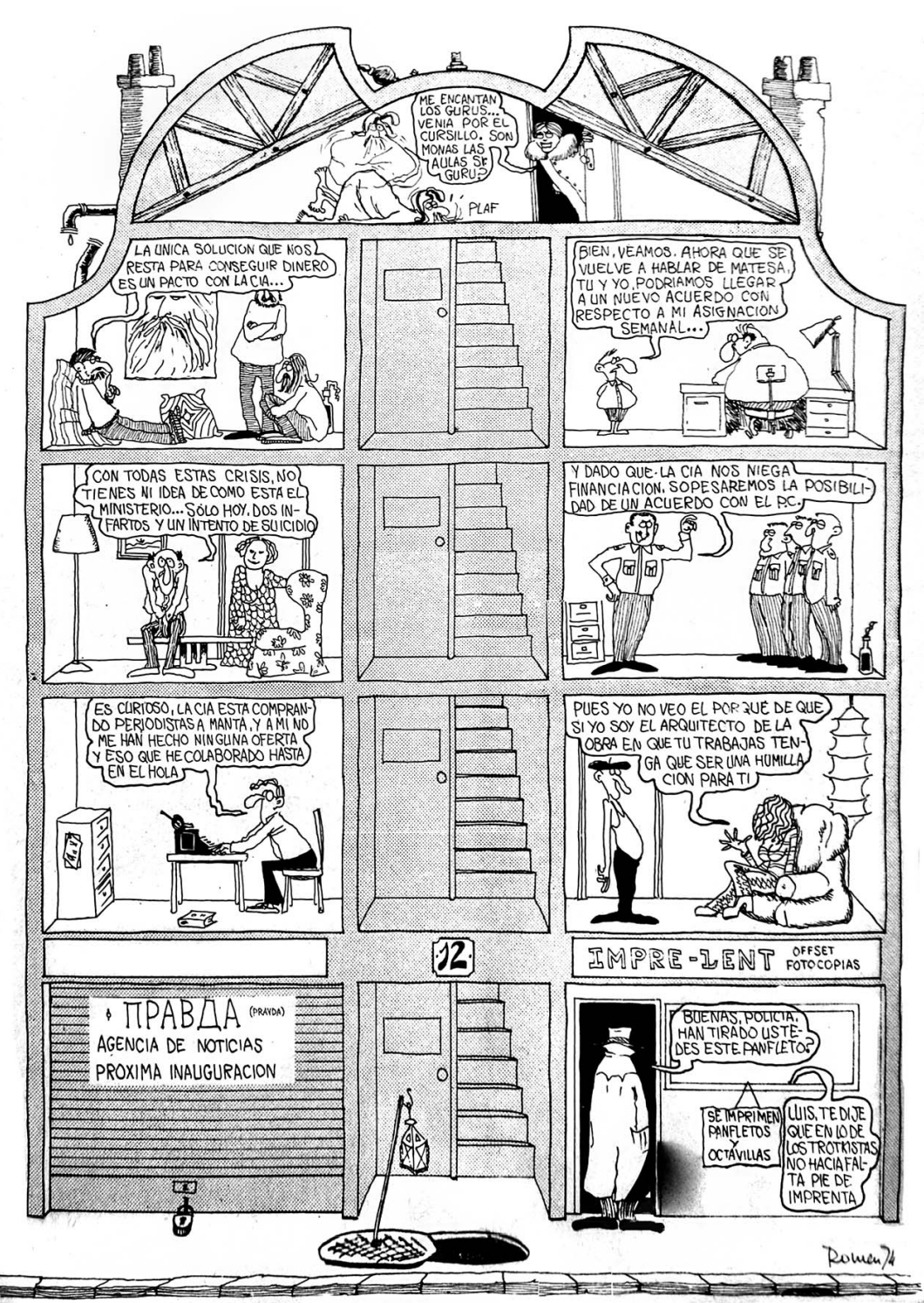

En la misma crítica a los estamentos sociales aparece Carpanta, personaje creado por Ibáñez para la revista Pulgarcito y publicada entre 1947 y 1969. Se representa el hambre de postguerra (Gasca, 1969: 152-153), de allí que haya interesado al lector adulto, porque no deja de ser un reflejo de la depauperada situación marcada por la falta de alimentos, la carestía y el fallo de las instituciones. Es un personaje marginado que tiene como única finalidad poder comer, de allí el pozo de sadismo al que se refiere Antonio Martín (2000: 135), una catarsis de los dibujantes para salir de la cruda realidad. Una situación que ha variado en 1974 cuando Guillén tergiversa su nombre por el de Carapanta [5] substituyendo el apetito físico por el sexual. El personaje es Woody Allen, aunque en la segunda viñeta aparece el mismo Carpanta diciendo «Veré si mi amigo Protrasio tiene un muslito a quien clavarle el diente», cambiando una vez más el nombre de su compañero de aventuras, le dice que le presentará a su prima que viene del extranjero, a quien llevará a una fiesta de disfraces. Las evidencias a la inmigración son evidentes, así como de la modernidad de aquellos que regresan. En este caso una mujer exuberante a quien Carapanta querrá seducir. El juego de personajes y las conexiones con 

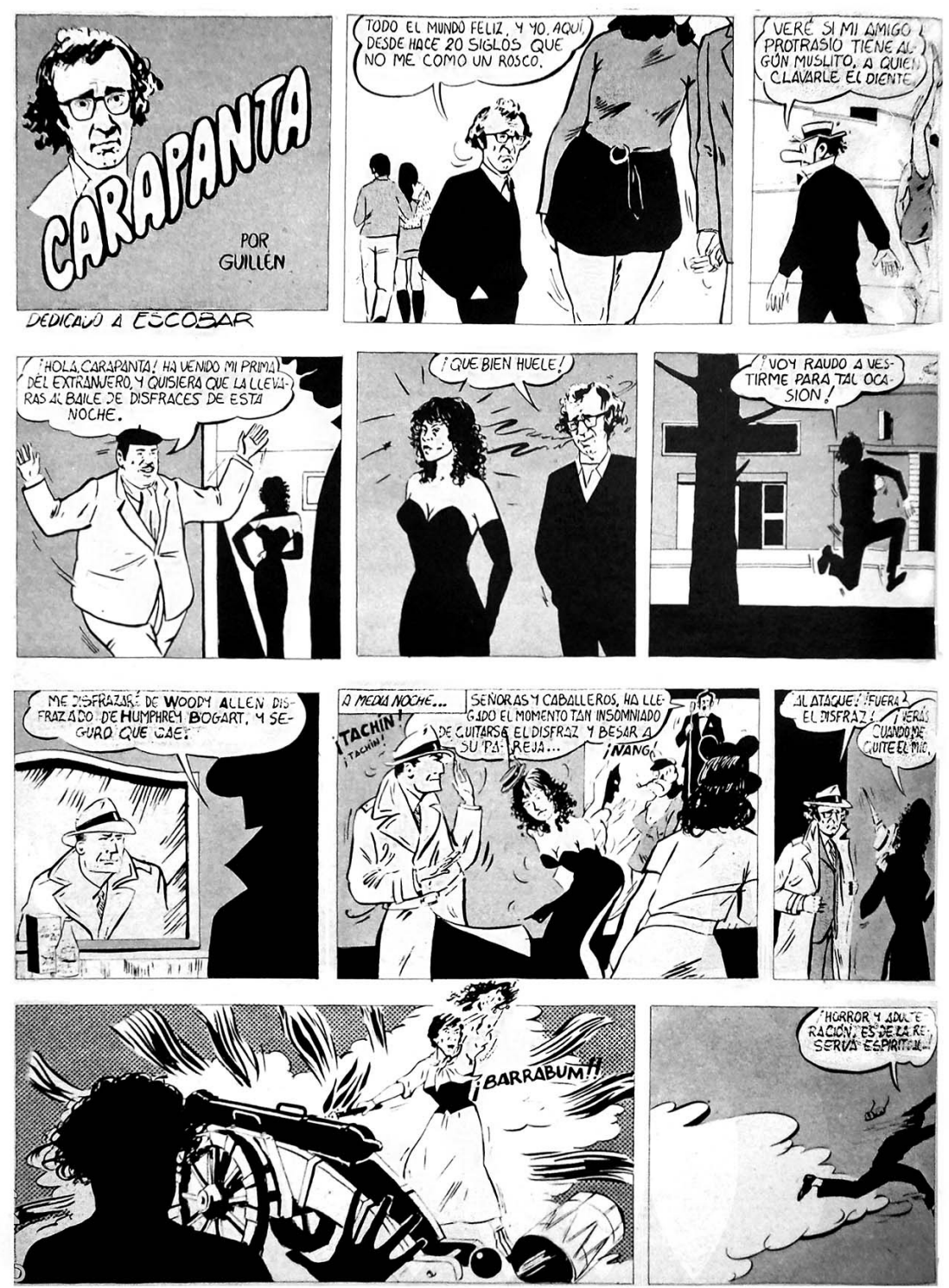

5. Guillén, «Carapanta», Por Favor, n. ${ }^{0} 3$, 18-03-1974, p. 32. Col. Arxiu històric de la ciutat de Barcelona la pintura y los mass media deviene enriquecedor, ya que dice se disfrazará de Humphrey Bogart, mientras observa a Dick Tracy (Chester Gould 1931-1977) ya reinterpretado por Roy Lichtenstein. Una imbricación compleja que va uniendo personajes de cómic, actores de moda y pop art, para finalizar con una mutación de la supuesta mujer liberada que nos recuerda a uno de los Desastres de la Guerra de Goya, concretamente ¡Qué valor! De modo que a la sofisticada mezcla de elementos antes anunciados debemos añadir la referencia a Goya, tal como lo hizo también el Equipo Crónica. Un compendio de imágenes icónicas que finaliza como las historias de Carpanta sin conseguir saciar su apetito sexual, puesto que la mujer representa a la reserva espiritual.

\section{Reapropiaciones americanas}

No podemos obviar que algunos movimientos plásticos habían introducido el valor icónico de los medios de comunicación de masas como es el caso del pop art. Con raíces en la aportación pionera de Richard Hamilton en Inglaterra se desarrolló en EE. UU. a partir de los años sesenta y ca- 
pitaneado por Andy Warhol y Roy Lichenstein reproducían personajes emblemáticos como Superman, Dick Tracy o Mickey Mouse (Gasca y Mensuro, 2014: 306), que fueron transformados hasta convertirse en iconos de un movimiento de vanguardia, a la vez que en la esencia de los valores del american way of life. En España, el Equipo Crónica, nacido hacia 1964 (Llorens, 1972: 9-10) con la finalidad de colocar los fenómenos culturales en la conciencia colectiva a través de imágenes de fácil reconocimiento, recurrieron a la pintura española de Velázquez, El Greco, Goya o Picasso, por considerar que arrastran una fuerte carga social y política así como los mass media (Equipo Crónica, 1981: 106), concretamente el cómic de filiación norteamericana sin olvidar el español, para denunciar o simplemente plasmar los miedos, angustias, frustraciones y ambiciones. A partir de imágenes muy conocidas, se les dará una nueva lectura gracias a la emulación o reapropiación.

Partiendo de las conexiones con el pop art, Equipo Crónica y el cómic americano, los superhéroes ocupan un papel privilegiado, aunque no serán los únicos personajes revisitados. Símbolo de la virtud del heroísmo altruista, emplean sus poderes en beneficio de los demás (Waid, 2010: 21), de allí la atracción de personajes como Superman, Batman o de otros que sin ser superhéroes como The Spirit comparten sus principios.

Superman (Siegel y Schuster, 1933) es un personaje dotado de poderes superiores gracias a los cuales lucha contra el mal. Eco lo define como un hombre heterodirigido (1988: 248), ya que vive en una comunidad de alto nivel tecnológico y en una estructura económica que es la sociedad de consumo, llegando a transmitir una pedagogía paternalista a la vez que ejemplo de conciencia cívica. Los dibujantes españoles lo utilizaros a dos niveles, como crítica a la Guerra del Vietnam y como promotor del cambio económico, social y político de España. En el primer caso, disponemos de un temprano artículo de La Codorniz, en el cual se identifica al superhéroe con Estados Unidos como responsable de la guerra:

Los americanos están haciendo una guerra terrible. Tanques, helicópteros, poderosamente armados y blindados, siembran la destrucción en la jungla. El pobre campesino es abrasado junto al guerrillero. A mi me parece que están haciendo una guerra de «tebeo»; inspirada en una de esas guerras interplanetarias en las que las armas más poderosas y extrañas ani- quilan al enemigo del héroe. Y en esta guerra de «tebeo», Norteamérica se ha reservado el papel de Superman (1967: 3).

La identificación es más ideológica que estética pudiendo destacar numerosos ejemplos que lo subrayan. En Hermano Lobo existen diversas versiones humorísticas, como el españolizado "Supermán González" » de Chumy Chúmez o con cara de vietnamita ${ }^{10}$ en clara referencia a la guerra en el sureste asiático. Se transgrede el papel de Superman como icono norteamericano que pasa a identificarse con el país atacado.

Vinculado a la política española, Chumy Chúmez realizó dos páginas tituladas «Súper-Sos contra la inflación» [6]. En doce viñetas, las multinacionales informadas sobre la inflación española, envían a Superman para que investigue las causas. A lo largo de su visita le irán ocurriendo una serie de aventuras que definen la España actual: le roban la cartera y solicita hablar con las asociación de «Supermanes», recibiendo como respuesta que en España no existen; es atacado por un grupo de tecnócratas, economistas y críticos; o conoce a un grupo de jóvenes reivindicativos. Visita los suburbios y compara a sus habitantes con los «negros» pero al conocer a los ricos, dice que «son como nosotros». En Barcelona entra en contacto con Garriga, amigo de los Kennedy y asociado con Rockefeller. En síntesis, una parodia del papel ejercido por Estados Unidos en la economía española.

En 1971 se autorizó la publicación Superman y Batman, una noticia publicada en La Codorniz, que duda sobre los verdaderos motivos:

Este servidor no sabe como interpretar la reaparición de «Superman» $y$ «Batman» a partir del 15-XII-71 como un inicio de aperturismo (tenue, infantil, pero aperturismo al fin), o como una sutil contribución a esa alienación particular a niveles de cultura popular, pues en su día, los argumentos en contra de estos mitos tebeísticos fueron los de la transmisión al lector de elevado porcentaje de sugestiones eróticas, racistas y violentas ¿Aperturismo? ¿Alienación? (1972: 3).

La crítica a las relaciones con los Estados Unidos son una evidencia así como una manipulación de los medios de masa a fin que el «amigo americano» viera la difusión de sus productos culturales. Romeu y Quequelis ${ }^{11}$ en Por Favor no dudarán en recurrir a Batman (Bon Kane y Bill Finger, 1939) 


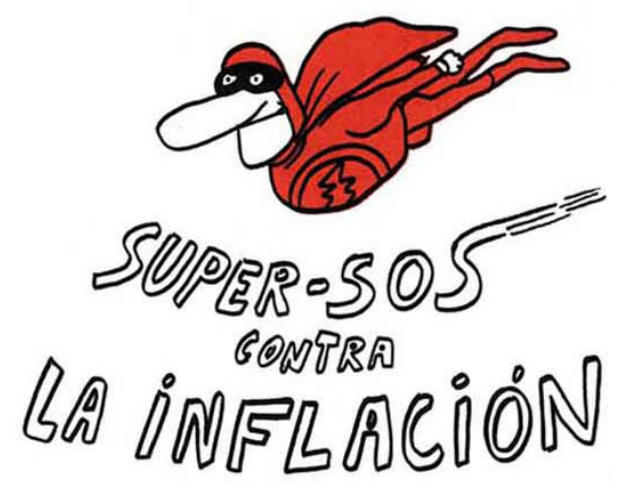

Enteradas clertas multinacionales yanquis del brote Inflacionista hispánico, deciden enviar a Supermán en misión especial «SOS n para que investlgue con objetividad sobre el caso. Supersos se pone en camino.
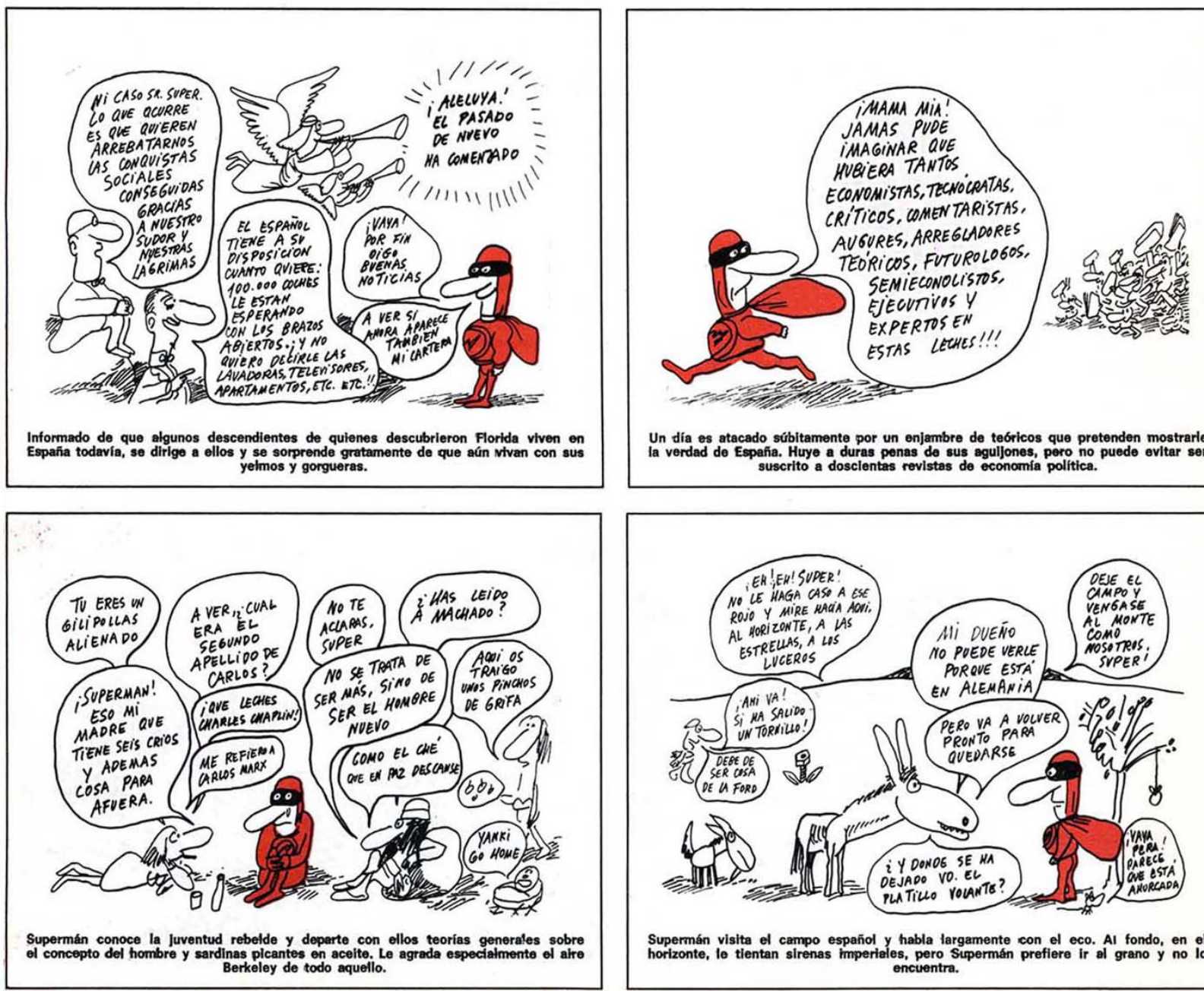

Un día es atacado súbitamente por un enjambre de teóricos que pretenden mostrarle la verdad de Espafía. Huye a duras penas de sus aguljones, pero no puede evitar ser suscrito a dosclentas revistas de economia politica.

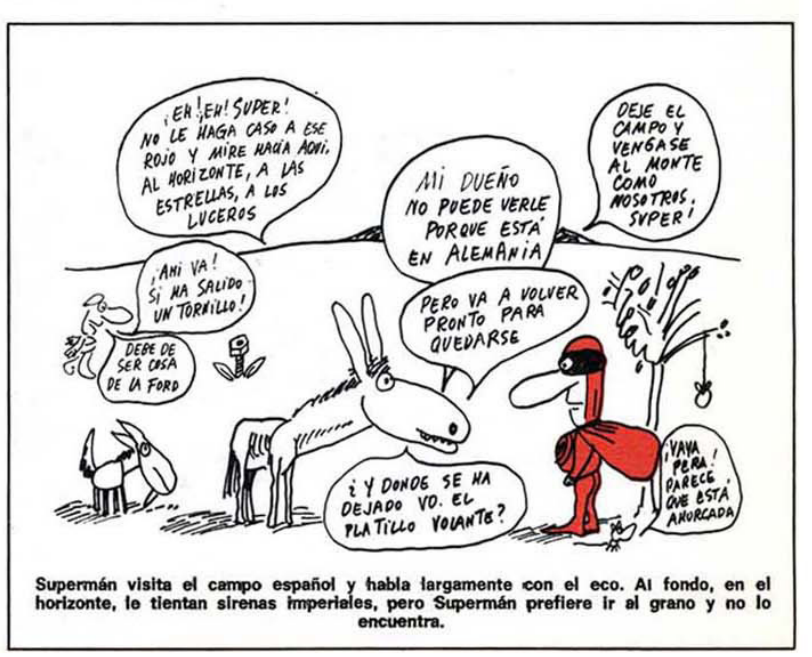

6. Chumy Chúmez, «Super-Sos contra la inflación», Hermano Lobo, n. ${ }^{0}$ 138, 28/12/1974, p. 8. Fuente: http://www.hermanolobodigital.com/ mostradorn.php?a\%F10=II\&num=138\&imagen=8\&fecha=1974-12-28 (consulta: 24/10/2017) 
para mostrar el escepticismo ante la corrupción. Parten de una viñeta original, seguramente calcada o recortada, para recurrir luego a un trazo rápido y nervioso, así como una disposición asimétrica de viñetas inconexas. Un policía detiene a Batman y Robin a pesar que están persiguiendo al responsable de la corrupción del caso de la Redondela ${ }^{12}$. Finalmente en tres momentos, Batman se desenmascara y su rostro es el de Kissinger.

La corrupción fue tratada por Romeu ${ }^{13}$ al revisitar Flash Gordon (Alex Raymond 1934), introductor de un nuevo imperialismo que defiende a Occidente de la amenaza comunista, imponiendo la democracia por la fuerza (Vázquez de Parga, 1980: 137). El gran enemigo de este héroe anglosajón es el emperador Ming, un trasunto de los emperadores totalitarios de Extremo Oriente y que encarna al "peligro amarillo» (Gubern, 2002: 107). La página comienza con dos viñetas en italiano, ya que este personaje llegó a España a partir de la versión italiana de la casa Nerbini, la cual se encargaba de adaptar las historias para la Italia fascista de 1935 (Martín, 2008). En su nave espacial se trasladan hacia el planeta Mongo y en tres viñetas apuntan que la vista del caso Matesa ${ }^{14}$ es para el mes siguiente y que un testigo de la causa Redondela ha patinado, para concluir luchando contra un monstruo al que acusa de haber atentado contra el príncipe Barín del Reino de Arboria, uno de los reinos de Ming y donde Barín había conseguido instaurar la paz. Siguiendo a Vázquez de Parga, es un reyezuelo impuesto por Flash Gordon, una nueva forma de dictadura reafirmando la ideología del héroe (1980: 137-138). En la misma revista, Vives recupera el tema de la Guerra del Vietnam, Flash es llamado por el presidente de los Estados Unidos, encarnado en el emperador Ming [7]. Se produce una inversión de los hechos de modo que los vietnamitas resultan los vencedores.

The Spirit (Will Eisner, 1940) si bien no es un superhéroe, es un personaje enmascarado, hecho que le permite asumir una doble personalidad. Un joven criminólogo que lleva una pequeña máscara, mientras que el resto de su indumentaria es la propia del género negro: gabardina, sombrero y guantes. La aportación de Eisner es la ruptura con las coordenadas convencionales y crear un espacio en el que no hay un punto de vista fijo (Masota, 1982: 93). Unos recursos utilizados por Manel (Manel Ferrer Estany) en «Nuevas técnicas» [8]. Un título que da lugar a dos interpretaciones. Comienza con una confesión del dibujante que acaba
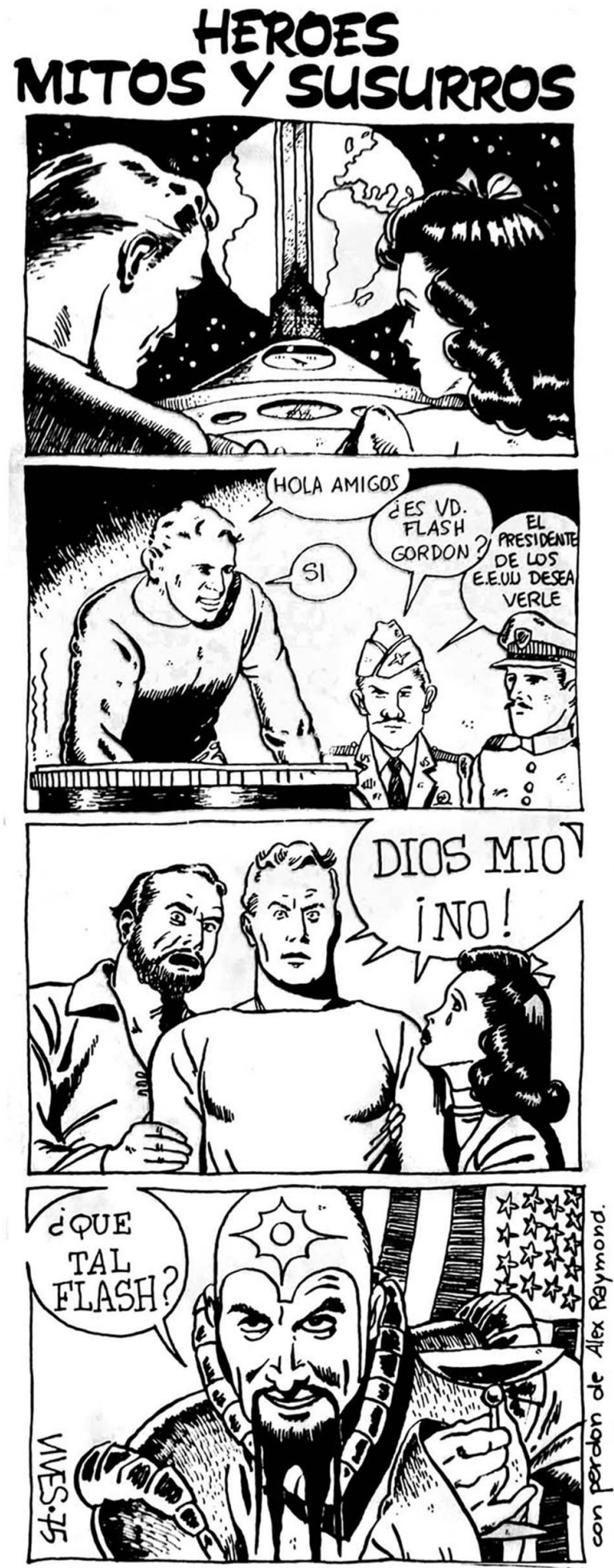

(Dibujos: VIVES)

7. Vives, «Héroes, mitos y susurros», Por Favor, n. ${ }^{0}$ 51, 23/06/1975, p. 17. Col. Arxiu històric de la ciutat de Barcelona 


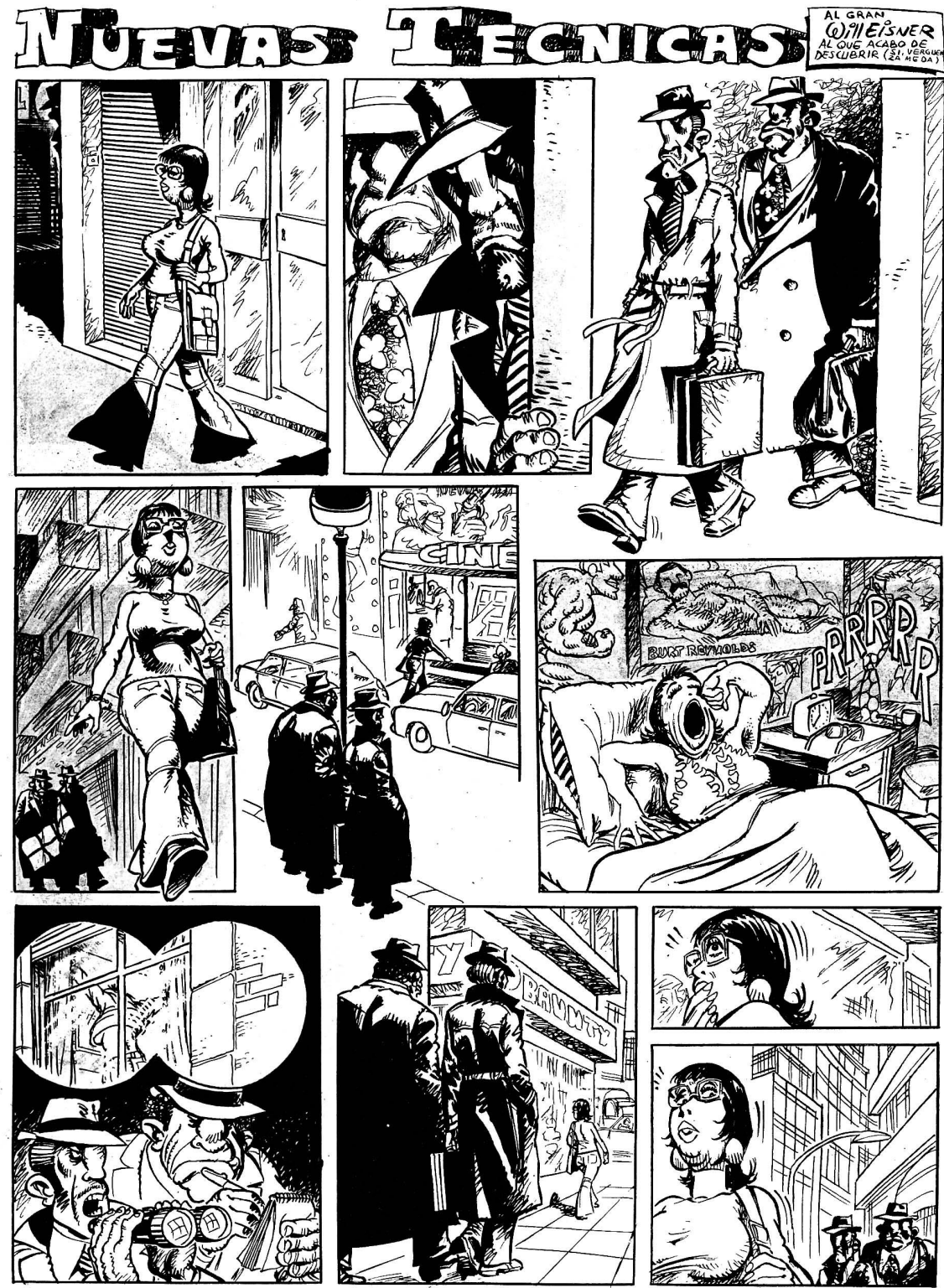

8. Manel, «Nuevas técnicas», El Papus, especial otoño, p. 51. Col. Biblioteca Nacional de Catalunya de descubrir a Will Eisner, cosa que no debe sorprender, ya que en 1975 se había vuelto a publicar en España por la editorial Garbo. Las técnicas en las que alterna planos detalle, primerísimos planos, picados y contrapicados, le permitieron conocer nuevas formas de dibujar, hecho comprobable al comparar las dos páginas con otras de sus realizaciones. Además, la temática es de tipo social; dos supuestos detectives espían y siguen a una mujer que vive sola, va al cine o se desnuda. Siguiendo los criterios de Eisner lleva la tensión a las últimas viñetas donde se descubre que los detectives son vendedores de productos para mujeres solas. De ahí la doble lectura del título, así como la referencia a los nuevos comportamientos femeninos.

Al margen de superhéroes o detectives, encontramos la saga de Charlie Brown (Charles Schulz, 1950) cuyos personajes son transgredidos por Vives. En el primer caso, estructura la página en ocho viñetas, las cuatro primeras dedicadas a Charlie Brown y las siguientes a Mafalda, bajo el título de «El plagio es bueno si va seguido de asesinato» [9]. La historia de Charlie Brown se centra en una escena 
9. Vives, «El plagio es bueno si va seguido de asesinato", Por Favor, n. ${ }^{\circ} 48,2 / 06 / 1975$ p. 32. Col. Arxiu històric de la ciutat de Barcelona

\section{EL PLAGIO ES BUENO SI VA SEGUIDO DE ASESINATO}
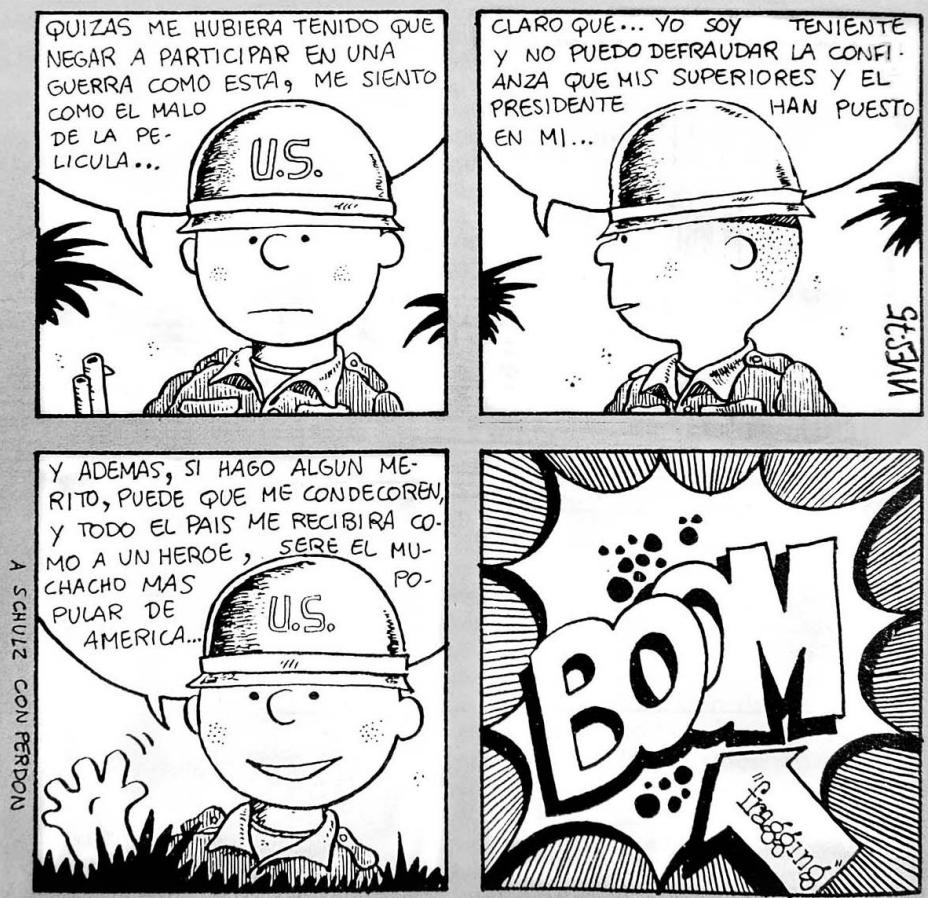

SISTEMA POR EL CUAL LOS SOLDADOS DESCONTENTOS POR LA GUERRA DE VIET-NAN SE DESHACIAN DE LOS OFICIALES MUY BELI COSOS (FRAGGING: DERIBADO DE BQMBA DE FRAGMENTACION de guerra, reflexionando sobre su participación o no, concluyendo que su intervención es para no defraudar a sus superiores y ser condecorado como un héroe. Si nos atenemos al análisis de Eco, este personaje busca cariño y cree que debe seguir las fórmulas de acomodo de la sociedad a través de los amigos o la cultura. Unas formas de relación con las que no acaba de sentirse cómodo (1988: 275). El fracaso de Charlie Brown en el final de Vives es el mismo ya que muere a causa de un fragging, que era el sistema por el cual los soldados descontentos con la guerra del Vietnam se deshacían de los oficiales más belicosos.

En «La noche del licántropo ${ }^{15}$ recurre a Snoopy. A través de seis viñetas un hombre se transforma en Snoopy una noche de luna llena. Un personaje que vive en un aparheid continuo, tiene la psicología del segregado. Sabe que es un perro pero le gustaría ser otras cosas, volviendo siempre a la realidad uniéndose a quien le da cariño (Eco, 1988: 278). De allí que la viñeta final es fruto de la reflexión, «que licantropía más tonta».

Y para finalizar, analizaremos Little Annie Spanish, una versión de Ventura y Nieto [10] de Little Annie Fanny (Harvey Kurtzman, 1963-1988). Esta parodia de Little Orphan Annie es un ejemplo de ataque a los iconos culturales del maccarthismo nacionalista. Publicada en Playboy resulta un exponente del cómic underground ya que a través de sus personajes efectúa una crítica incisiva a temas de actualidad como el arte, cine o televisión. Una parodia social en la que Kurtzman denuncia la manipulación del atractivo sexual de la 


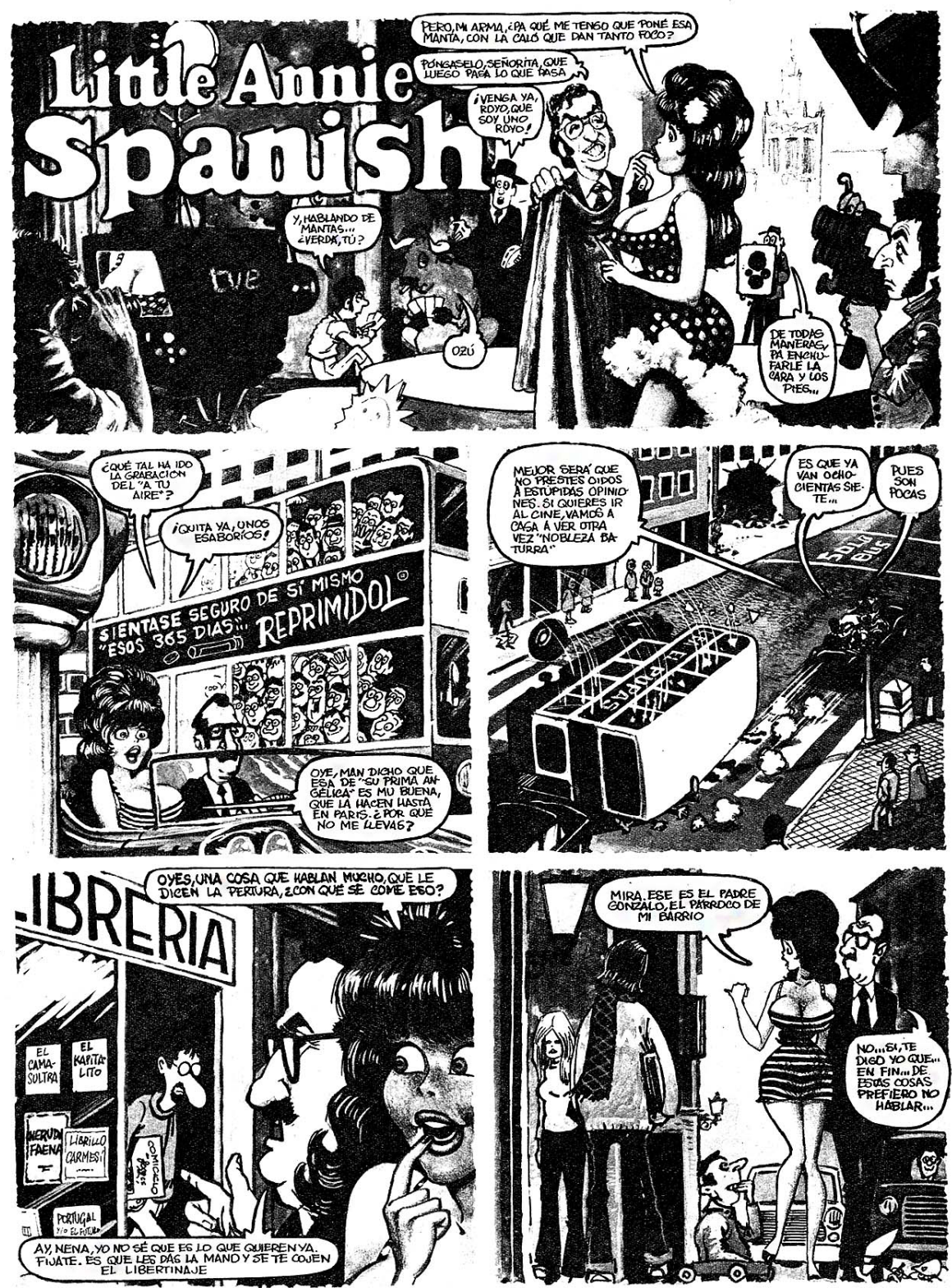

10. Ventura \&Nieto, «Little Annie Spanish», El Papus, n. ${ }^{\circ} 52$, 11/10/1974, p. 6. Col. Biblioteca Nacional de Catalunya

protagonista (Guiral, 2012), quien a través de su sinceridad pone en evidencia la ridiculez de los hombres que buscan en ella favores sexuales. En oposición a la rubia protagonista, Ventura y Nieto la presentan como una actriz morena cuyo novio es un tópico del español medio. Gracias a los diálogos se extrae que tiene intereses políticos y culturales, a pesar que los demás la ven simplemente como un objeto sexual. No deja de ser una sátira de la sociedad española que no termina de aceptar a la mujer liberada.
Conclusiones

Si bien la desmitificación de los cómics americanos o españoles es una de las pautas que nos permiten acercar las revistas de humor satírico a los planteamientos del underground, no podemos dejar de lado otras cuestiones más profundas. El hecho de recurrir a modelos preexistentes determina que el medio se convierte en fin a la vez que adquiere estatuto de objetivo y permite sacar a la luz lo que estaba 
oculto, llegando a configurar un medio en si mismo que es el cómic autonímico o el cómic en el cómic. Al analizar dialécticamente los ejemplos escogidos, destaca la existencia de una verdadera mímesis desde el punto de vista gráfico, ya que en muchos de los casos partían del calco de los originales o simplemente los recortaban. Este hecho en ningún caso supone un plagio, ya que la voluntad del dibujante es darle una nueva lectura, que en muchos casos se consigue a través de la descontextualización de los personajes. En otras ocasiones se optó por un espontaneísmo gráfico, entendiendo que el dibujo es la expresión de una idea y una vez expresada con claridad había cumplido su función.
La irreverencia del trato con los personajes revisitados o si se quiere su parodia, dará lugar a nuevas lecturas e incluso a una nueva mirada sobre los mismos, entendiendo la ideología en que nacieron y que urgía desmontar.

Retomando la afirmación de Eco (1988: 269), al tratarse de unas revistas dirigidas a un público adulto, el humor no fue edulcorado y muchos menos inocuo, generando una lectura críptica que permitirá crear un espacio de opinión respecto al retraso cultural y político de los cuarenta años del franquismo. No en vano fueron denominadas «Parlamentos de papel» ya que encarnaron un verdadero debate político desde la sociabilidad intelectual (De la Cuadra, 2012: 2).

\section{Notas}

1 El presente artículo forma parte de los resultados derivados del proyecto del Ministerio de Economía y Competitividad bajo el título «Los fundamentos del cambio cultural en España (1960-1975)» (HAR 2014-52882-P).

2 Entendemos por revistas de humor satírico aquellas publicaciones de periodicidad semanal destinadas a un público adulto con contenidos críticos articulados a través de editoriales, artículos o reseñas y donde las viñetas o ilustraciones ocuparon un papel significativo. El precedente inmediato es $L a$ Codorniz nacida en 1941 (Tubau, 1987:63-64).

3 A partir de los años 60 y 70 del siglo XX en países como Francia e Italia surgió un cómic con contenidos dirigidos al público adulto gracias a la inclusión de historias cuyas temáticas iban desde la contenidos socio-políticos, ciencia ficción, género negro o expresión de estados de ánimo. Todo ello sin olvidar la calidad plástica y los nuevos criterios de la narración. Consecuencia del régimen franquista, en España se habrá de esperar a finales de los sesenta para que los dibujantes españoles comiencen a interesarse por dichas temáticas y formas de expresión por los cual, algunos dibujantes iniciaron a finales del franquismo un exilio laboral a fin de publicar sus producciones en Europa (Lladó, 2001: 25).

4 A modo de ejemplo, en 1975 fueron secuestrados diversos ejemplares de El Papus, Destino, Posible, Cambio 16, Triunfo, Star, además del encarcelamiento del periodista José María Huertas de Tele Express (Conde Martín, 2005: 1102-1107).

5 La contracultura puede definirse como un paradigma que incluye manifestaciones artísticas, científicas o filosóficas contrarias o diferentes a la cultura oficial. Es otra forma de ver la realidad al margen de postulados hegemónicos (Herrera, 2009: 73).

6 ROMEU, «Guerrero del Antifaz revisited», Por Favor n. ${ }^{\circ}$ 9, 29-4-1974, p. 27.

7 GUILLÉN, Por Favor n. ${ }^{\circ}$ 23, 9-12-1974.

8 VIVES, «Héroes, mitos y susurros», Por Favor n. ${ }^{\circ}$ 68, 20-10-1975, p. 17.

9 CHUMY CHÚMEZ, "Superman González», Hermano Lobo n. ${ }^{\circ}$ 178, 4-10-1975, p. 2.

10 CHUMY CHÚMEZ, Hermano Lobo n. ${ }^{\circ} 157$, 10-05-1975, p. 18.

11 ROMEU Y QUEQUELIS, «Batman», Por Favor n. ${ }^{\circ}$ 13, 27-05-1974, p. 25.

12 El caso Redondela consistió en la desaparición de 4.502 toneladas de aceite de oliva en la mencionada localidad viguesa, situación que provocó el aumento del precio de dicho producto. En «El caso del aceite de Redondela: Procesamiento del señor Alfonso Fariña»: https://inz.march.es/documento.asp?re$\mathrm{g}=\mathrm{r}-48846$ (Consulta 29/09/2017)

13 ROMEU, «Flash Gordon», Por Favor n. ${ }^{16}$, 17-06-1974, p. 28.

14 El caso Matesa se relaciona con la corrupción del empresario catalán Vila Reyes, vinculado al Opus Dei. Habiendo obtenido un importante crédito del Estado, buena parte del capital desapareció en verano de 1969. El gobierno de Franco eludió el tema, siendo indultado en 1971 (Minuesa, 2005: 225-228).

15 VIVES, «La noche del licántropo», El Papus n. ${ }^{\circ} 70,15-02-1975$, p. 30.

\section{Bibliografía}

ALTARRIBA, Antonio (2001), La España del tebeo. La historieta española de 1940 a 2000, Espasa Calpe, Madrid.

CLAUDIO, Esther (2014), "La proyección social del cómic estadounidense en la España tardofranquista», Nueva Revista del Pacífico, n. ${ }^{\circ}$ 61, pp. 56-84.

CONDE MARTíN, Luis (2005), El humor gráfico en España. La distorsión internacional, Asociación de la Prensa Gráfica, Madrid. 
CUADRA, Bonifacio de la (2012), «El papel de la prensa en la Transición», en VIII Jornadas de Estudios sobre Franquismo y Transición. En: <https://previa.uclm.es/ab/humanidades/seft/pdf/actividades/12/ALBACETEPRENSATRANSICION2012.pdf> (fecha de consulta: 2610-2017)

DOPICO, Pablo (2005), El cómic underground español, 1970-1980, Cátedra, Madrid.

ECO, Umberto (1988/1968), Apocalípticos e integrados, Lumen, Barcelona.

EQUIPO CRÓNICA (1981), «Datos sobre la formación del Equipo Crónica y Cronología por series», Equipo Crónica, catálogo de la exposición, Ministerio de Cultura, Dirección General de Bellas Artes, Archivos y Bibliotecas, Subdirección General de Artes Plásticas, Madrid.

FALCÓN, Lidia (2014), «Carlos París, un gigante del pensamiento». En: <blogs.publico.es/lidia-falcon/2014/01/30/carlos-paris-un-gigante-del-pensamiento/> (fecha de consulta: 29-09-2014).

FONTES, Ignacio y MENÉNDEZ, Manuel (2004), El parlamento de papel. Las revistas españolas de la transición española, Asociación de la Prensa de Madrid, Madrid.

GARRIDO ZANÓN, Carla (2010), «El Espiritu del 12 de febrero en el semanario de humor Hermano Lobo», en BORDERIA, Enrique y otros (ed.), La risa periodística. Teoría y metodología e investigación en comunicación satírica, Tirant lo Blanch, Valencia, pp. 165-172.

GASCA, Luis (1969), Los cómics en España, Lumen, Barcelona.

GASCA, Luis y MENSURO, Asier (2014), La pintura en el cómic, Cátedra, Madrid.

GUBERN, Román (2002), Máscaras de la ficción, Anagrama, Barcelona.

GUIRAL, Antoni (2012), «Little Annie Fanny: erotismo con mensaje o mensaje con erotismo». En: <https://www.tebeosfera.com/documentos/little_annie_fanny_erotismo_con_mensaje_o_mensaje_con_erotismo.html (fecha de consulta: 11-10-2017).

La Codorniz, n. ${ }^{\circ} 1311,1967$, p. 3.

- n. ${ }^{\circ} 1582,1972$, p. 3.

HERRERA ZAVALETA, José Luis, (2009), «Filosofía y contracultura», Quaderns Textos n. ${ }^{\circ}$ 39, pp. 73-82. En: <https://www.uv.es/sfpv/quadern_textos/v39p73-82.pdf> (fecha de consulta: 03-05-2018).

LLADÓ POL, Francisca (2001), Los Cómics de la Transición (El boom del cómic adulto 1975-1984), Glénat, Barcelona.

LLORENS, Tomàs (1972), Equipo Crónica, Gustavo Gili, Barcelona.

MAFFI, Mario (1975/1972), La cultura underground, Anagrama, Barcelona.

MARIMÓN, Antoni (2005), Guerrers, corsaris, soldats i detectius, Documenta Balear, Palma.

MARTíN, Antonio (2000), Apuntes para una historia de los tebeos, Glénat, Barcelona.

- (2008), «Las primeras ediciones de Flash Gordon en España: 1935.1971». En: <https://www.tebeosfera.com/documentos/las_primeras_ediciones_de_flash_gordon_en_espana_1935-1971.html> (fecha de consulta: 15-10-2017).

MASOTA, Óscar (1962), La historieta el en mundo moderno, Paidós, Barcelona.

MINUESA, Bernat (2005), Dictadura y Transición. La España Lampedusiana. I: La dictadura franquista, Barcelona, Universitat de Barcelona, 2005.

MOIX, Terenci (2007). Historia social del cómic, Ediciones Bruguera, Barcelona.

RAMíREZ, Juan Antonio (1975), La historieta cómica de postguerra, Cuadernos para el Diálogo, Madrid.

TUBAU, Iván (1987), El humor gráfico en la prensa del franquismo, Editorial Mitre, Barcelona.

VÁZQUEZ DE PARGA, Salvador (1980), Los cómics del franquismo, Planeta, Barcelona.

VIDAL, Jaume, GUIRAL, Antonio, ESPAÑA, Ramón de y FIDALGO, Sergio (1999), De Yellow Kid a Superman. Una visión social del cómic, Fundació Josep Comaposada, Barcelona.

WAID, Mark (2010), «La auténtica verdad sobre Superman (y sobre nosotros)», en MORRIS, Tom y MORRIS, Mat (eds.), Los superhéroes y la filosofía, Blackie Books, Barcelona, pp. 21-32. 